\title{
Mesenchymal Stem Cell and MicroRNA Therapy of Musculoskeletal Diseases
}

\author{
Myung-Jin Chung ${ }^{1, *}$, Ji-Yoon Son ${ }^{1, *}$, SunYoung Park ${ }^{1,2}$, Soon-Seok Park ${ }^{1}$, Keun Hur ${ }^{3}$, Sang-Han Lee ${ }^{4}$, \\ Eun-Joo Lee ${ }^{1}$, Jin-Kyu Park ${ }^{1,2}$, Il-Hwa Hong ${ }^{5}$, Tae-Hwan Kim ${ }^{1}$, Kyu-Shik Jeong ${ }^{1,2}$ \\ ${ }^{I}$ Department of Pathology, College of Veterinary Medicine, Kyungpook National University, Daegu, Korea \\ ${ }^{2}$ Stem Cell Therapeutic Research Institute, Kyungpook National University, Daegu, Korea \\ ${ }^{3}$ School of Medicine, Kyungpook National University, Daegu, Korea \\ ${ }^{4}$ Department of Food Science E Biotechnology, Kyungpook National University, Daegu, Korea \\ ${ }^{5}$ Department of Veterinary Pathology, College of Veterinary Medicine, Gyeongsang National University, Finju, Korea
}

The therapeutic effects of mesenchymal stem cells (MSCs) in musculoskeletal diseases (MSDs) have been verified in many human and animal studies. Although some tissues contain MSCs, the number of cells harvested from those tissues and rate of proliferation in vitro are not enough for continuous transplantation. In order to produce and maintain stable MSCs, many attempts are made to induce differentiation from pluripotent stem cells (iPSCs) into MSCs. In particular, it is also known that the paracrine action of stem cell-secreted factors could promote the regeneration and differentiation of target cells in damaged tissue. MicroRNAs (miRNAs), one of the secreted factors, are small non-coding RNAs that regulate the translation of a gene. It is known that miRNAs help communication between stem cells and their surrounding niches through exosomes to regulate the proliferation and differentiation of stem cells. While studies have so far been underway targeting therapeutic miRNAs of MSDs, studies on specific miRNAs secreted from MSCs are still minimal. Hence, our ultimate goal is to obtain sufficient amounts of exosomes from iPSC-MSCs and develop them into therapeutic agents, furthermore to select specific miRNAs and provide safe cell-free clinical setting as a cell-free status with purpose of delivering them to target cells. This review article focuses on stem cell therapy on MSDs, specific microRNAs regulating MSDs and updates on novel approaches.

Keywords: Mesenchymal stem cells, Induced pluripotent stem cells, Cell therapy, Musculoskeletal disorder, MicroRNA, Exosome

Received: October 13, 2020, Revised: November 24, 2020,

Accepted: November 30, 2020, Published online: December 31, 2020 Correspondence to Kyu-Shik Jeong

Department of Pathology, College of Veterinary Medicine, Kyungpook National University, 80 Daehakro, Bukgu, Daegu 41566, Korea

Tel: +82-53-950-5975, Fax: +82-53-950-5955

E-mail: jeongks@knu.ac.kr

*These authors contributed equally to this work.

(c) This is an open-access article distributed under the terms of the Creative Commons Attribution Non-Commercial License (http://creativecommons.org/ licenses/by-nc/4.0/), which permits unrestricted non-commercial use, distribution, and reproduction in any medium, provided the original work is properly cited.

Copyright (c) 2021 by the Korean Society for Stem Cell Research

\section{Introduction}

The musculoskeletal system includes muscle, joint, bone, nerves, and tendons that support the body by aiding movement and maintaining posture. Musculoskeletal diseases (MSDs) refer to injury or pain of the musculoskeletal system caused by many factors, including the repetition of the same work task, aging, and genetic problems (1). MSDs have become a common problem for people all over the world because these diseases are considered the leading contributor to disability globally with difficulty in the assessment prognosis factors of the disorder (2). In addition to humans, various studies are being con- 
ducted in animal models such as murine, canine, and equine, with fatal musculoskeletal diseases. Developments in regenerative medicine for conditions associated with tissue damage and aging have progressed, and the search for stable and safe cell therapies, as well as non-cell therapies, have become emerging challenges.

Cell therapy refers to a treatment that injects, grafts, or implants viable cells such as $\mathrm{T}$ cells or stem cells into the damaged tissues to induce regeneration. For decades, stem cell transplantation has been gaining considerable attention, especially among biologists, as a potential technology for various disease states with degenerative and immunogenic pathologies. Among the different types of stem cells, adult stem cells are used the most as therapeutic agents because their tendency to be stable and safe at therapeutic levels, but these cells are arduous to expand and obtain enough at this point. For instance, mesenchymal stem cells (MSCs), a type of adult stem cells, are collected in various body areas such as bone marrow, fatty tissue, cord blood, and synovium (3). The ability of MSCs to differentiate into multiple cell types makes them ideal for use as a treatment in a wide range of diseases, including immune-modulatory therapy, ischemia, bone and cartilage regeneration, myocardium regeneration, and the treatment of skeletal and neurological disorders $(4,5)$. However, the amount of tissue-derived MSCs is limited, and even if they are cultured in vitro, the rate of proliferation decreases as they age (6). Also, the health conditions of donors could impact negatively on the quality of MSCs (7, 8). Therefore, several studies have involved the development and utilization of MSCs differentiated from induced pluripotent stem cells (iPSCs), which are reprogrammed from somatic cells to maintain stable MSCs. These studies have shown that iPSC-derived MSCs are a better option than tissue-derived MSCs in terms of proliferation rate and quality (9-11). Stem cell niche is a specialized microenvironment for the preparation of excessive stem cell production and progression into cancer, but could also enable regulated replication for progenitor production and tissue repair where necessary. Thus, stability is an essential quality of a functional stem cell niche to ensure the sustenance of stem cell characteristics and their growth regulation (12) to avoid the tendency of their advancement into malignancy.

MicroRNAs (MiRNAs) are paracrine substrates in the transplantation of MSCs, which form a niche. Reports have pointed out that small molecules, miRNAs are critical materials for biological processes (13-16). MiRNAs are small non-coding RNA molecules containing about 22 nucleotides, which functions in RNA silencing and post-tran- scription to regulate gene expression (17-19). Research on miRNAs has been expanding due to their roles as regulators of gene expression, which are related to target diseases, and thus, they are promising for biomarkers development. Besides, cell-to-cell transportation, as well as signaling of miRNAs via the paracrine route, is achieved through the extracellular vesicles (EVs). EVs are categorized into two types, depending on size: exosomes and microvesicles (20); in particular, non-cell therapy using EVs secreted from MSCs have recently become an emerging treatment (21-24). Therefore, in this study, we have considered compiling treatments that have progressed to date using tissue- or cell-derived MSCs for MSDs, and have shown recently emerged new treatments using non-cell therapy, MSC-secreted miRNAs, and their biological effects on MSDs.

\section{MSC}

\section{Tissue-derived MSCs}

There are three types of adult stem cells known as hematopoietic stem cells (HSCs), MSCs, and nerve stem cells (NSCs). Especially, with MSCs, which are the cells used for regenerative medicine, they are capable of maintaining stemness and self-renewal capacity, as well as the inclination to differentiate into various mesenchymal tissues (chondrocytes, myocytes, adipocytes, tenocytes, and osteocytes). Besides, since MSCs are immunomodulatory, and enable possible allotransplantation and xenotransplantation. On the whole, MSCs can be extracted from bone marrow, fatty tissue, cord blood, synovium, bone tissue, and infrapatellar fat, and differentiated from pluripotent stem cells.

Bone marrow (BM)-derived MSCs are non-HSCs located in the medullary stroma of bone marrow. BM-MSCs were discovered by Friedenstein et al. in 1976 (25). Typically, they are extracted from iliac, femur, tibia, and sternum bone. The extraction of BM-MSCs could result in serious problems, such as pain, bleeding, infection, or even death (26). On the other hand, extraction of adipose-derived mesenchymal stem cells (ASCs) is relatively easy and safe, and thus, it is possible to extract significant amounts, compared with other tissue-derived MSCs (27-29). The chromosomal stability of ASCs is higher than BM-MSCs in the effects of continuous subcultures, suggesting they could attain normal proliferation and differentiation status (30). In addition, according to published data, ASCs have advantages of proliferative capacity compared with BM-MSCs. However, BM-MSCs exhibit an enhanced ability of osteogenic and chondrogenic differentiation, where- 
as ASCs display advantages in adipogenic differentiation potential, indicative of their cellular naive and homing status (31). There is evidence to support that the type of tissue and the anatomical region from which MSCs are extracted play an essential role in determining their regenerative capacity. Synovium-derived MSCs were first identified and isolated in 2001 (32). They are increasingly recognized as promising therapeutic cell types for musculoskeletal regeneration, especially for cartilage, muscle, and tendon remodeling. Among the MSCs, synovium-derived MSCs present enhanced proliferation capacity and advances in chondrogenesis, compared with MSCs derived from other tissues $(33,34)$. Previous studies have shown that umbilical cord blood (UCB) derived MSCs are able to expand and be conserved for treatments. Also, the harvesting of UCB-MSCs is less invasive and safe for both mother and infant. Due to the immaturity of neonatal cells, UCB-MSCs have advantages over other tissue-derived MSCs, as they exhibit higher proliferative capacity, and minimized immunologic reactivity, thereby, lessening the risk of graft-versus-host disease. For the past several decades, UCB banking for future use has become popular (35).

\section{Induced pluripotent stem cell-derived MSCs}

MSCs can be isolated from many tissue types, but they populate only approximately $0.001 \%$ to $0.1 \%$ of cells throughout the body (6), and as the age of the person increases, the collected number and quality decrease $(7,8)$. Therefore, much focus has been based on attempts to derive MSCs from pluripotent stem cells.

iPSCs: The pluripotency of embryonic stem cells (ESCs) has shown tremendous potential for cell therapy. However, ethical concerns regarding taking cells from embryo limit its therapeutic approach (36). To overcome this limitation, technology has been developed to generate iPSCs from somatic cells. Unlike ESCs, iPSCs are recognized as the most promising cells in various therapies because their utilization does not pose ethical problems. IPSCs possess the characteristic of pluripotency, which is induced by transcription (37). These transcription factors commonly include a combination of Oct4, Sox2, Klf4, and c-Myc (OSKM) (38, 39); other than OSKM, other transcription factors induce reprogramming with high efficiency of somatic cells into pluripotent stem cells to increase the expression of specific genes, like those of the glycolytic pathway and gene responsible for the regulation of self-renewal $(40,41)$. The use of iPSCs favors challenges encountered with ethical issues $(38,42)$, and current research depends on using integrative viral vectors such as retrovirus and lentivirus, and non-integrative vectors, including adenovirus, episomal plasmids, RNAs, along with attempts to introduce proteins as defined transcription factors by transduction techniques into somatic cells to restore pluripotency as fast, easy and safe methods for obtaining pluripotency cells. However, iPSCs, which had been studied for therapeutic purposes, failed to pass the genomic validation step and has resulted in a decision to suspend this research area temporarily because of encountered mutation challenges. Whether the cause of iPSCs mutation already exists in a patient's fibroblast or in the reprogramming process themselves, is still unclear (43).

Differentiation to MSCs: MSC-like cells derived from iPSC have similar morphology when compared with MSCs such as ASCs, peripheral blood-MSCs, or UCB-MSCs. To differentiate these iPSCs into MSCs and obtain a high rate of proliferation is a vital process in stem cell medicine, as it supplies enough cells for MSC-based therapies (9). IPSC-MSCs are known to play a role in suppressing inflammation. According to our published data, the cell cycle statuses of equine-iPSC-MSCs and equine ASCs were assessed by flow cytometry, which revealed that ASCs were less proliferative than our iPSC-MSCs. iPSC-derived MSCs are also similar to those derived from tissues in terms of their immunophenotype and multipotency toward differentiation into mesodermal cells, such as chondrocytes, myocytes, adipocytes, and osteocytes. These observations were confirmed by the expression level data obtained from MSC surface markers such as $\mathrm{CD}^{+}{ }^{+}, \mathrm{CD} 90^{+}$, $\mathrm{CD}_{105}{ }^{+}, \mathrm{CD}_{146}{ }^{+}$, and $\mathrm{CD} 166^{+}$, which lacked expression of TRA-1-60 ${ }^{-}$and CD34- which are pluripotent markers and hematopoietic markers respectively $(10,11)$. Also, research on iPSC-derived MSCs has proven that $\mathrm{CD}^{+}$ $\mathrm{FOXP}^{+}$Tregs that control anti-inflammatory activities are enhanced by iPSC-MSC-mediated immunosuppression when injected. This finding shows the potential of iPSCMSC to maintain immune compromise and tolerance (44). The result of other studies showed that the increase in expression of functional channels in iPSC-MSCs was cause of higher cell proliferation rates than BM-MSCs (45). These cells from iPSC-derived could be useful as potential cell resources to MSDs.

\section{Direct conversion to MSCs}

In addition, MSCs can also be converted from mature cells that are completely differentiated, such as somatic cells. Direct conversion is a process that induces conversion between completely different cell types. Currently, direct conversion is recognized as a possibility of being used in disease modeling and new drug discovery, and in 
the future, it will be applied to gene therapy and regenerative medicine. OCT4 was directly programmed into patient-specific somatic cells and established as MSCs (46). In addition, an episomal or lentiviral vector-mediated OCT4 expression allowed human CD34(+) cells to be programmed directly to MSC quickly and efficiently (47). The direct conversion of fibroblast to muscle stem cells was done using transcription factors, including EYA1, Pax3, Esrrb, and Sixl (48). Crucially, the direct conversion programming of chemical-induced somatic cells to MSCs is possible and increases the strong clinical potential, but to date protocols are limited (49).

\section{Therapy using different types of MSCs}

Currently, MSCs treatments commonly used in various diseases include surgery, radiotherapy, and chemotherapy. Although these methods are effective, they also bring collateral damages and adverse effects to healthy tissue (50). To overcome the limitations, cell therapy, which involves transplantation of cells to repair or replace damaged tissue and/or cells, has been developing rapidly not only in humans, but also in veterinary medicine, including its application in the treatments of dogs, cats, and other companion animals, including horses, for many types of diseases (9). Cell transplantations are divided into autologous, allogeneic, and xenogeneic. Autologous cell transplantation refers to the use of the patients' own cells, cultured, and expanded in vitro and reintroduces into the patient. Allogeneic cell transplantation uses the cells collected from another individual among the same species, while xenogeneic cell transplantation involves cross-species cell transplantation, utilizing cells from different animal sources (50). Early clinical trials using animal models revealed the therapeutic potential of MSC transplantation for ischemic diseases such as heart coronary artery disease, peripheral arterial disease, and stroke (51). Numerous types of cells, including BM-MSCs, ASCs, and iPSC-MSCs, which are being presented as appropriate targets $(52,53)$. The two possible mechanisms of MSC transplantation are: 1) recruitment of MSC to the injury site and transformation into normal cells which compose the host cytoarchitecture and support stroma and 2) paracrine mechanism (54). Many research teams have confirmed the efficacy of MSC treatment for musculoskeletal diseases in various species via anti-inflammatory action possibly due to the soluble paracrine manner factors that will be discussed later (Table 1).

BM-MSCs: BM-MSCs have made extensive application of clinical practice based on in vitro studies of isolation, incubation, and differentiation. Typically, the therapeutic use of BM-MSCs is applied to the treatment of osteoarthritis, immune disorder diseases, neurodegenerative diseases, and sports medicine, both autologously and allogenically (25). For example, autologous chondrocyte implantation has predominantly been applied for cartilage repair in cases in which a small biopsy of cartilage provides a chondrocyte population that is expanded in vitro and implanted into the cartilage defect in a second operation. Allogeneic BM-MSCs have also been explored in osteoarthritis therapy of the knee. In a multicenter study, the pain-reducing effect of allogeneic BM-MSCs relative to hyaluronic acid alone was observed in patients with primary idiopathic osteoarthritis of the knee portion. Based on rodent model studies, such as mice, rats, and guinea pigs, allogeneic BM-MSCs were injected in C57BL/6 for therapeutic purposes for post-traumatic arthritis. The results showed that synovitis or activated macrophages were not reduced in the synovium, but the cytokine levels and bone healing response were altered. Based on this data, the authors raised the possibility that BM-MSCs could prevent post-traumatic arthritis (55). Among those, allogeneic BM-MSCs were used to treat tendon injury and osteoarthritis, which revealed increased healing capacity (56-59). Interestingly, the potential for future treatments using xenogeneic (heterologous) MSCs has been demonstrated using human MSCs in rats, and guinea pigs have by several research groups $(60,61)$. Favorably, even in rabbits and dogs, allogeneic BM-MSCs showed excellent therapeutic effects on osteochondral defects and osteoarthritis (62-64). Many cell therapy studies have been conducted in horses, in which musculoskeletal diseases were fatal; although these studies did not show clearly the establishment of successful treatments, there were expectations of positive outcomes regarding treatments of autologous BM-MSCs in the future, given the significantly improved level of aggrecan (65), a cartilage-specific proteoglycan core protein, and thus, indicated cartilage repair. In addition, stem cell therapy is also applied in livestock such as sheep (66). Other research groups have also reported that autologous BM-MSCs provided significant enhancement in the normalization of biomechanical, morphological, and compositional parameters and that they were expected to contribute to the development of cell therapy in humans (67-70). Clinical trials are being conducted not only in animals but also in humans to confirm the progress of osteoarthritis by treating knee injuries with autologous BM-MSCs with osteoarthritis outcome core and magnetic resonance imaging (MRI). The stability and efficiency of cell therapy were proven by evaluating the condition of the patients after half a year to 2 years. As a 
Table 1. Therapeutic effects of diverse mesenchymal stem cells

\begin{tabular}{|c|c|c|c|c|}
\hline Treatment & Species & Type of Lesion & Autologous/Allogeneic/Heterologous & References \\
\hline \multirow[t]{13}{*}{ BM-MSC } & Mouse & Osteoarthritis & Allogeneic & (55) \\
\hline & Rat & Tendon defect & Allogeneic & $(56-58)$ \\
\hline & & Osteoarthritis & Allogeneic & (59) \\
\hline & & & Heterologous & (74) \\
\hline & Guinea pig & Osteoarthritis & Heterologous & (61) \\
\hline & Rabbit & Osteochondral defect & Allogeneic & (62) \\
\hline & & Osteoarthritis & Allogeneic & (63) \\
\hline & Dog & Osteochondral defect & Allogeneic & (64) \\
\hline & Sheep & Osteoarthritis & Autologous & (99) \\
\hline & Horse & Tendon defect & Autologous & $(66-68)$ \\
\hline & & Osteochondral defect & Autologous & $(65,69)$ \\
\hline & Human & Osteoarthritis & Autologous & $(70,71,75-81)$ \\
\hline & & & Allogeneic & $(72,74)$ \\
\hline \multirow[t]{5}{*}{ ASC } & Mouse & Muscular dystrophy & Allogeneic & (85) \\
\hline & Rabbit & Osteoarthritis & Allogeneic & (82) \\
\hline & Dog & Osteoarthritis & Autologous & (83) \\
\hline & Human & Osteoarthritis & Allogeneic & (100) \\
\hline & & & Autologous & $(86,87)$ \\
\hline \multirow[t]{2}{*}{ Synovium-MSC } & Rabbit & Osteochondral defect & Allogeneic & $(88,89)$ \\
\hline & Pig & Cartilage & Allogeneic & $(90,91)$ \\
\hline \multirow[t]{6}{*}{ UCB-MSC } & Rabbit & Osteochondral defect & Heterologous & (93) \\
\hline & & Rotator cuff tendon tear & Heterologous & (94) \\
\hline & Horse & Tendon defect & Allogeneic & (101) \\
\hline & & Joint & Autologous & (92) \\
\hline & & & Allogeneic & (92) \\
\hline & Human & Osteoarthritis & Allogeneic & $(95,96)$ \\
\hline \multirow[t]{6}{*}{ iPSC-MSC } & Mouse & $\mathrm{DMD}$ & Allogeneic & (102) \\
\hline & Rabbit & Cartilage & Heterologous & (103) \\
\hline & Pig & Bone fracture & Heterologous & (98) \\
\hline & Horse & Osteoarthritis & Allogeneic & (10) \\
\hline & & Joint & Allogeneic & (10) \\
\hline & & Tendon defect & Allogeneic & (10) \\
\hline
\end{tabular}

result, waking distance, clinical data, and visual analog scale were proved $(71,72)$. Allogeneic injections of BMMSCs have been attempted to verify the stability of cells rather than their therapeutic effect $(72,73)$. Clinical research in humans is underway, and there are claims that cell therapy has demonstrated a potential of stability and feasibility (72-81).

ASCs: ASCs are also used as a treatment like MSCs, with similar efficacy to BM-MSCs. ASCs were used as a treatment for osteoarthritis in rabbits or dogs. Allogeneic treatment of ASCs reduced the symptoms of osteoarthritis, but further experiments need to be conducted to validate the maintenance and stability of these treatments (82). Autologous ASCs were transplanted in dogs with osteoarthritis, and the results indicated significantly increased peak vertical force and vertical impulse levels (83). Also, the use of ASCs in muscle regenerative therapies has been discussed by other research groups. In vivo skeletal muscle regeneration experiments, cells with increased myogenic capacity were found using ASCs, which demonstrated the presence of myoprogenitor population in ASCs. Therefore, these myoprogenitor ASCs were identified as specific surface markers, and were obtained through isolation and expansion, and shown to have the potential in skeletal muscle treatment (84). According to previous research, combined ASCs with losartan treatment enhanced the therapeutic effects on muscle injury in mice by improving the restoration of muscle fibrosis and regeneration (85). As with BM-MSC, clinical treatment of ASCs was carried out in humans, and the apparent recovery was confirmed in autologous ASCs $(86,87)$. Furthermore, treatment of allogeneic ASCs was also applied to a wide range of osteoarthritis patients (88).

Synovium-MSCs and UCB-MSCs: Although syno- 
vium-MSCs have not been applied much in treatments, they were shown to be effective in chondrogenic regeneration and have been used in several studies (89-92). In other tissue-derived MSCs, autologous/allogenic UCBMSCs were compared within horses. Based on the stability, allogeneic UCB-MSCs showed their prospects as a treatment for the joint defect (93), and the tendon defects (94) in the future. Also, human UCB-MSCs were injected in rabbits that contributed to the development of treatment for the musculoskeletal disease $(95,96)$. Furthermore, clinical treatments have been carried out in humans (97, 98).

iPSC-MSCs: Disease treatments using tissue-derived MSCs showed some undoubted efficacy; nonetheless, other results were reported to be non-significant. In the early days, the lack of knowledge of biological mechanisms and low engraftment efficiency of MSCs could have resulted in a weak therapeutic effect in clinical trials. Because the quality of MSCs varies widely among donors, MSCs induced from pluripotent stem cells, such as ESCs and iPSCs, could provide safe and ideal source (99). The use of iPSC-MSCs as a regenerative medicine showed significant radiological and histomorphometrical results rather than what was reported in a previous study using autologous tissue-derived MSCs (100). According to other studies on the therapeutic effects of iPSC-MSCs, they demonstrated better effectiveness than BM-MSCs in reducing severe hind-limb ischemia and promoting vascular, along with muscle regeneration (11). When iPSC-MSCs were Injected into musculoskeletal injured areas, including osteoarthritis mainly, bone fracture, osteochondritis, and tendonitis in horses, the results indicated the improvement of these defects by reducing lameness and fever without any adverse effects (10). Taken together, iPSCMSCs are considered as powerful tools for regenerative medicine than any other tissue-derived MSCs $(101,102)$.

\section{Potential of Cell-Free Therapy}

\section{Stem cell niche}

Niche regulates the microenvironment so that stem cells regenerate damaged tissue, facilitate rapid repair, and prevent overgrowth of tissue. Such stem cells interact by exchanging various feedback signals from their immediate microenvironment. Secreted signals originate from the stem cells themselves (autocrine), adjacent niche cells (paracrine), or other tissues, creating a stem cell niche condition (103). Secreted signals control stem cell fate relative to proliferation and differentiation (104), among which EVs that carry various genetic material plays an im- portant role. Therefore, the ability of self-renewing, maintaining stemness, and differentiation of stem cells depend on the niche, and communication between stem cells and niche is important to control their fate. Interestingly, among various types of targeted resources such as cytokines, RNAs, proteins, etc., miRNAs have become critical sequences since they are important mediator of stem cell niche establishment (105).

\section{Exosome therapy}

Numerous recent studies have shown positive effects through various mechanisms of MSCs, among which EVs of MSCs are regarded to have an essential role in immunomodulation and regeneration of damaged tissue (21). EVs include microvesicles, nanoparticles, apoptotic bodies, and exosomes (23). Microvesicles have been studied mainly for their role in blood coagulation, but have recently been reported to be involved in cell-to-cell communication in various cell types, including cancer cells and stem cells, and are generally called oncosomes $(106,107)$. Microvesicles range in size from 50 to $1,000 \mathrm{~nm}$ in diameter, but they can be as large as $10 \mu \mathrm{m}$ in some cases. They are produced from the plasma membrane of a cell and released into the extracellular space by outward budding (108). Exosomes are small EVs engendered in endosomal membranes. There is currently no clear definition of exosomes, as they have not yet been studied widely. Exosomes are composed of lipid-bilayer vesicles with a diameter of 30 to $100 \mathrm{~nm}$ and a density of 1.13 to $1.19 \mathrm{~g} / \mathrm{ml}$. Essentially, exosomes are vesicles formed from the membrane of the mutivesicular endosome through inward budding. They are secreted into extracellular fluids by fusion of multivesicular endosomes and the cell surface (Fig. 1) (109). The ability of the above-mentioned cell therapy using MSCs to treat musculoskeletal tissue injury was attributed to musculoskeletal cell differentiation. On the other hand, MSC secretome (mainly referring to exosomes) suggests that they are an essential component in controlling the microenvironment (niche) of injured tissue and regenerative processes, such as cell migration, proliferation, and matrix synthesis (110). Exosomes contain proteins, lipids, DNA, RNA, and small non-coding RNAs, including miRNAs. Although it has been widely proven that the lipid contained exosome plays an important role in the stability of vesicle, the effect of the lipid-derived from MSC-exosome is still being explained (111). About 2,000 proteins were identified in exosomes derived from MSCs. The membrane proteins of exosomes derived from MSCs are proteins attached to the GPI, tetraspanins, and receptors. Besides, proteins in MSC-derived exosomes in- 


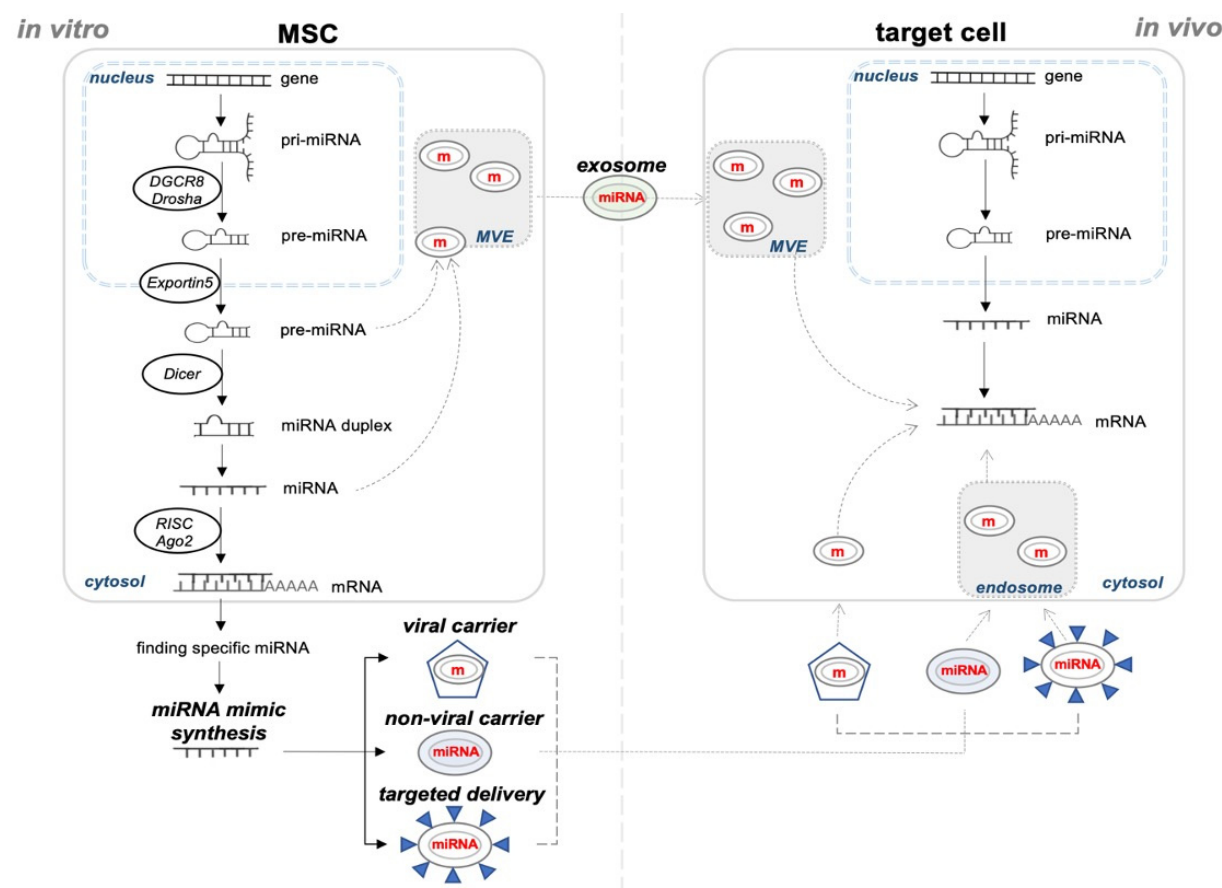

Fig. 1. Process of cell-free therapy from MSCs to target cells. In cell-free therapy, there is a method of transmitting exosome secreted from MSCs to target cells, and a method of selecting specific miRNA in MSCs, then synthesizing it in the formed mimic and delivering it to target cells. A transport is needed to deliver miRNA mimic to target cells in vivo. Generally, viral/non-viral carrier and targeted delivery are used. clude endogenous proteins such as annexin2, antigen-presentation proteins like MHC-I and MCH-II, cell adhesion such as integral and MEFGE8, and cellular structures and motility proteins including actin, myosin, and tubulin (112-114). Among the components of exosome entering the target cell, miRNAs are one of the most important small molecules since they affect the gene expression the most compared with other molecules (115).

There are several advantages of using exosome-based therapy which is cell-free therapy. The low immunogenicity, no effect on vascular obstructive and reduced risk of secondary microvascular thrombosis, potential development of engineering therapeutic vesicles, amplification of ligand-gate signaling pathways and transference of biomolecules from stem cells to target tissue, ability to convert content of miRNA in exosome $(116,117)$. These advantages let the research on exosome-based therapy underway. Exosome secreted from BM-MSCs showed therapeutic effect in MSDs such as ischemia (118), femur fracture (119), and muscle injury (120). To confirm the therapeutic effect of exosome from iPSC-MSC, researchers obtained exosome from culture medium of human iPSCMSCs by purifying it. Exosome was prepared in hydrogel glue and treated in a rabbit model with osteochondral defect. As results, integration of injected hydrogel glue with native cartilage matrix was observed, and deposition of cell within the site of cartilage defect was promoted indicating the enhancement of the therapeutic effect of iPSC-MSC-derived exosomes (121). In addition, the abil- ity of iPSC-MSC-derived exosomes was demonstrated in MSD by treating exosome without cells (122). Also, the treatment of exosome from iPSC-MSCs to hind-limb ischemia or bone loss proved the improvement of its symptoms $(123,124)$. Although few research compared exosomes secreted by tissue-derived MSCs and iPSC-MSCs, in one paper by $\mathrm{Yu}$ Zhu compared the therapeutic effect of exosome secreted by synovium-MSCs and iPSC-MSCs in the OA model. Both exosomes stimulated chondrocyte migration and proliferation, but the effect of exosomes secreted by iPSC-MSCs was higher (125). Moreover, compared with tissue-derived MSCs, iPSC-MSCs have proven superior in cell proliferation, immunomodulation, cytokine profile, generation of exosomes that can regulate microenvironment, and bioactive paracrine factor secretion $(126,127)$. It is assumed that exosome secreted from iPSCMSC is beneficial over exosome secreted from tissue-derived MSC. Because the therapeutic effects of iPSC-MSCs was superior to tissue-derived MSCs (10, 44, 45), they might secrete effectual extracellular vesicles which should be studied further. It is well known that not all MSC-derived exosomes are equivalent, depending on the condition and environment of the cells (128-130). Besides, for exosome therapy, a sufficient amount of exosome is required and subsequently, it requires a massive quantity of cells. Since the mass culture of iPSC-MSCs is available, using iPSC-MSCs rather than tissue-derived MSCs would be more efficient to extract an adequate number of the exosome. Exosome-based therapy not only complements 
limitations of cell therapy but can also provide a much safer treatment for patients in mild conditions who do not need to supplement the cells.

\section{MiRNA biogenesis}

MiRNAs in exosome are known to play an important role in target cells. But if only miRNAs were delivered into target cells, would the therapeutic effect be the same?; or how much therapeutic effect will it have? We will discuss the possibility of using miRNA and its limitations here. MiRNAs, one of the most predominant non-coding RNAs in EVs, are like hormones having abilities of autocrine, endocrine, and paracrine activities; therefore, they are essential in intercellular and intracellular communication (131). The role of miRNAs is crucial, especially in the development and differentiation of cells, regulation of cell cycle, metabolic control, and immune modulation. MiRNAs have been found to control more than $60 \%$ of all coding genes and play a central role in physiological processes, such as cell proliferation, differentiation, genome stability, metabolism, apoptosis, and aging (132-134).

MiRNAs, non-coding RNAs, are composed of about 22 nucleotides. Their primary function is blocking the translation of multiple genes, thereby, regulating the expression of numerous target genes through sequence-specific hybridization to the 3'UTR or the other site of mRNAs. The sequences of miRNAs come from intergenic or intron and exon which are located in intragenic region. They are initially transcribed as long primary transcripts by polymerase II in the nucleus and are called primary miRNA (pri-miRNA). This pri-miRNA contains 5' m7G cap structure and 3' poly(A) tail. Then, still in the nucleus, primiRNAs form stem-loop structures by dsRNA binding protein DGCR8 and RNase III endonuclease Drosha; which together are called microprocessor. The microprocessor cleaves both strands of the stem near the base of the primary stem-loop and produces a hairpin structure about 70-nucleotide-long sequence called miRNA precursor (pre-miRNA). Pre-miRNAs then are transported to the cytoplasm by a protein known as exportin 5 in the presence of the Ran-GTP cofactor. A second RNase III endonuclease, Dicer1, and dsRNA binding protein together cleave the loop of the pre-miRNA hairpin to produce an approximate $22 \mathrm{nt}$ double stranded miRNA. Subsequently, the miRNA duplex is unwound by helicase, generating a couple functional miRNAs. One of 2 single-stranded miRNAs, a leading strand, is preferentially transferred to as RNA-induced silencing complex (RISC), containing proteins together with Dicer and AGO2, which is the catalytic engine of RISC. Another strand, the passenger strand, is degraded. The mature miRNA guides RISC to 3' UTR of mRNA. They can inhibit translation or directly degrade the target mRNAs. These reactions depend on their complementarity to the target mRNA sequence (Fig. 1) (131).

\section{MiRNA delivery}

Even though we could discover the specific miRNA targeting disease relating gene, its complete and safe delivery without degradation into the target cell is in question. For example, favorable pharmacokinetic properties include increased serum half-life, serum protein stability, optimal biodistribution through the preferential transmission to target organs/cells and elimination by the renal or delusional endothelial system. in vivo delivery of siRNA or miRNA for therapeutics is one of the most essential problems needs to be solved (135). Mimics are artificially synthesized short nucleotide sequences having similar orders with pre-miRNAs. Like pre-miRNAs, they are recognized by the machinery of miRNA biogenesis and work as other miRNAs. microRNA-mimics (miR-mimics) have been investigated as a new source of non-cell therapy. When the expression of a specific miRNA is decreased in a particular disease state, induction of miR-mimics into the tissue helps to act like the miRNA (136). The transport of miRNA can be largely divided into viral/non-viral carriers and targeted delivery. Viral carriers uses vectors such as lentivirus, adenovirus, adeno-associated virus, but they are not suitable for treatment due to problems such as toxicity, immunogenicity, and mutation. Therefore, liposomeor polyethylenimine (PEI)-based delivery system without virus is developed and has been studied for clinical use (137). Liposomes are one of reagents commonly used in vitro, but due to toxicity, non-specific uptake, and unwanted immune response, there are limits to being used as a safe and efficient delivery in vivo (138). PEI is used a lot in gene delivery. PEI has a positive charge and goes through endocytosis by interacting a negative charge on the cell surface. Proton sponge occurs in the endosome and come out to cytoplasm (139). PEI has good transfection efficiency and no toxicity in this respect, but there is a limitation in delivering small molecules such as siRNAs or miRNAs (140). Compared to viral carriers, non-viral carriers are much less toxic and immunogenic, but less transfection efficiency. Nevertheless, further study of the aforementioned thresholds would be good transports in vivo. A targeted delivery, nanoparticle (NP), is literally a carrier attached to target cells by having a specific ligand. It is also possible to avoid immune response caused by macrophages and immune cells by making 
stealth coating on NP (Fig. 1) (141).

\section{Therapeutic potential of microRNAs for musculoskeletal diseases}

Despite the good results obtained from treatments, the mechanisms of their positive effects are only partially accommodated (142). Because MSCs show limitation in generating a consistent source of cells with a stable phenotype, graft injection by the host, and potential of tumorigenicity, researchers have begun to investigate other methods to compensate for the disadvantages of MSC transplantation. On this account, the development of miRNAs that bring therapeutic effects has been actively investigated. They are important regulators of the maintenance of pluripotency or multipotency and differentiation of stem cells. EV-derived miRNAs, thereby, are mediators of the extended paracrine effects of stem cells. Therefore, it could be inferred that the intercellular regu- lation of gene expression is mediated by the intercellular communication via transfer of miRNAs from EVs, and this ultimately affects the stem cell fate and their niches (143). Although miRNA therapeutics have not yet received FDA approval for medical intervention, candidate drugs of miRNAs are in process of development. So far, there are several clinical trials in the pipeline for miRNAs (144).

Table 2 indicates the different functions of miRNAs targeting different genes in musculoskeletal diseases. The therapeutic potential of BM-MSC-derived exosomes has been recognized primarily in degenerative diseases, such as intervertebral disc degeneration (142). In the osteoarthritis mouse model, the exosomes from BM-MSCs were involved in regulating the level of apoptotic chondrocyte (145). During osteogenic differentiation, exosomal miRNAs including let-7a, miR-199b, miR-218, miR-148a, miR-135b, miR-203, miR-210, miR-299-5p, and miR-302b from BMMSCs showed their significant decrease in human (146).

Table 2. The effectiveness of exosomes/miRNAs as targets for mesodermal lineage disorders

\begin{tabular}{|c|c|c|c|c|}
\hline Sources & miRNAs & In vitro & In vivo & References \\
\hline \multirow[t]{8}{*}{ BM-MSC } & miR-22 & & $\begin{array}{l}\text { Reduce apoptosis in ischemic cardiomyocytes, } \\
\text { ameliorated fibrosis and improve cardiac } \\
\text { function post-myocardial infarction in mice }\end{array}$ & (120) \\
\hline & $\begin{array}{l}\text { miR-4532, } \\
\text { miR-125b-5p, } \\
\text { and miR-4516 }\end{array}$ & & Promote fracture healing in mice & (121) \\
\hline & miR-494 & Promote myogenesis and angiogenesis & Promote muscle regeneration in mice & (122) \\
\hline & $\operatorname{miR}-92 a-3 p$ & $\begin{array}{l}\text { Enhance chondrocyte proliferation, } \\
\text { migration, and cartilage development }\end{array}$ & Inhibit cartilage degradation in mice & $(151)$ \\
\hline & miR-135b & Enhance chondrocyte proliferation & Enhance chondrocyte proliferation in rat & (152) \\
\hline & miR-885-5p & $\begin{array}{l}\text { Regulates BMP2-induced osteogenic } \\
\text { differentiation }\end{array}$ & & (147) \\
\hline & miR-320c & Enhance BMSC chondrogenesis & & (153) \\
\hline & $\operatorname{miR}-140-5 p$ & Promote adipocyte differentiation & & (154) \\
\hline \multirow[t]{4}{*}{ ASC } & miR-100-5p & $\begin{array}{l}\text { Inhibit cell apoptosis, promote anabolism } \\
\text { in IL-1 } \beta \text {-induced chondrocytes, and } \\
\text { enhance the level of autophagy }\end{array}$ & Prevent the cartilage destruction & (155) \\
\hline & & Exert a major neuroprotective role & & (156) \\
\hline & & $\begin{array}{l}\text { Promote proliferation, migration, and } \\
\text { osteogenic differentiation of BMSCs }\end{array}$ & $\begin{array}{l}\text { Promote bone regeneration in critical-sized } \\
\text { calvarial defects in mice }\end{array}$ & (157) \\
\hline & $\operatorname{miR}-218$ & Promote osteogenic differentiation & & (149) \\
\hline Synovium-MSC & miR-140-5p & $\begin{array}{l}\text { Activate YAP, decrease ECM secretion, } \\
\text { and induce proliferation and migration } \\
\text { of articular chondrocytes }\end{array}$ & $\begin{array}{l}\text { Slow the progression of early } \mathrm{OA} \text { and prevent } \\
\text { the severe damage of } \mathrm{OA} \text { in rat }\end{array}$ & (158) \\
\hline \multirow[t]{4}{*}{ iPSC-MSC } & & $\begin{array}{l}\text { Promote migration and proliferation of } \\
\text { chondrocytes and hBMSCs }\end{array}$ & $\begin{array}{l}\text { Provide a mode for cartilage regeneration and } \\
\text { promote integration }\end{array}$ & (123) \\
\hline & & $\begin{array}{l}\text { Promote osteoblast proliferation, } \\
\text { differentiation and bone formation }\end{array}$ & $\begin{array}{l}\text { Promote bone regeneration in critical-sized } \\
\text { calvarial defects in rat }\end{array}$ & (124) \\
\hline & & $\begin{array}{l}\text { Promote endothelial cell migration, } \\
\text { proliferation, and tube formation }\end{array}$ & $\begin{array}{l}\text { Promote blood perfusion and attenuate severe } \\
\text { hind-limb ischemia of mice }\end{array}$ & (159) \\
\hline & & Promote angiogenesis in endothelial cells & Prevent bone loss and increase angiogenesis in rat & $(160)$ \\
\hline
\end{tabular}


The specific miRNA secreted by BM-MSCs is actively studied in vitro $(147,148)$, and furthermore in vivo (149, 150). Let-7a regulates HMGA2 to improve osteogenesis and bone formation while inhibiting adipogenesis of human stromal/MSCs (151). MiR-199b was reported to be involved in controlling osteoblast differentiation by Runx2. Signals from the relationship between miR-218 and Wnt/ $\beta$-catenin have been known to promote osteogenic differentiation of human ASCs (152). In addition, many studies have been conducted with exosome and specific miRNA secreted by ASCs (153-155). Rarely, in vivo experiment was also carried out in the OA model of rat with miRNAderived synovium-MSCs treatment (156). Discovering and using the function of miRNAs have provided various therapeutic targets (Fig. 2). Taken together, with miRNAs being key components of the stem cell niches, which regulate stem cell fate, are potent sources of therapy and likely to be substituted for standard chemotherapy and stem cell therapy.

Although there are not many studies targeting MSDs, one study found some distribution of EVs in tibia and femur, especially in liver and spleen after intravenous injection of BM-MSC-derived EVs (157). This suggests that miRNAs in EV can also affect MSDs.

\section{Conclusions}

MSCs, which have been applied as therapeutic sources of various diseases, could be isolated from several different tissues, including BM, UCB, adipose tissue, and syno- vium, and could be induced from iPSCs. Their therapeutic effects have been validated in numerous reported scenarios of musculoskeletal diseases in humans and a variety of animal models. Many studies of BM-MSCs have been conducted, but have proved to be less effective after applying the treatment compared to other sources (158-163). In addition, using tissue-isolated MSCs rather than iPSCMSCs presents limitations, namely, the amount of MSCs harvested is usually not sufficient for continuous transplantation, and the process is invasive, as well as requiring preparation, and the cellular conditions might differ, depending on the statuses of the donors. Therefore, many researchers, including our group, are interested in iPSCMSCs and attempting to apply them for MSC therapy.

Meanwhile, it was discovered that the paracrine action is the primary mechanism of stem cell therapy, and could promote regeneration and differentiation of the damaged tissue by secreting transcription factors, proteins, and miRNAs to target cells. It is believed that the ultimate therapeutic effects resulted from the functions of secreted paracrine factors rather than the cells themselves. Among those factors, miRNA, a type of small non-coding RNA related to epigenetic regulation, inhibits the translation of not only one gene but possibly many genes. Thus far, numerous research endeavors are underway to study miRNAs for therapeutic purposes. Researchers have proposed the possibility of miRNA administration as a form of therapy to avoid any safety problems caused by MSC transplants such as arrhythmic (164), tumorigenesis, ossification, and calcification in tissue (165). However, there are still limi-

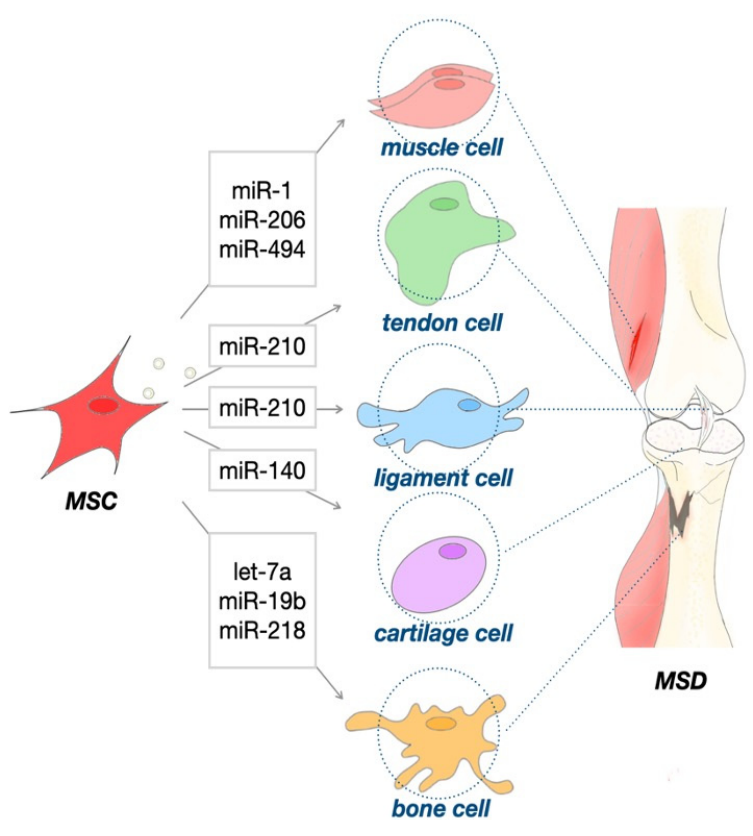

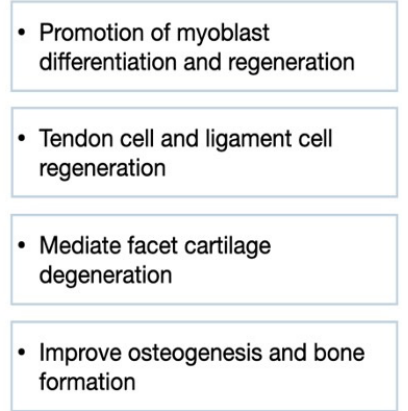

formation
Fig. 2. MSC-secreted miRNA therapy for musculoskeletal diseases. As shown in the figure above, different miRNAs secreted by MSCs act on target cells show a positive effect on musculoskeletal diseases. As shown in table 2 , there are many miRNAs related to musculoskeletal diseases. Further, it was confirmed that one miRNA could target different genes in different cells giving different effects. 


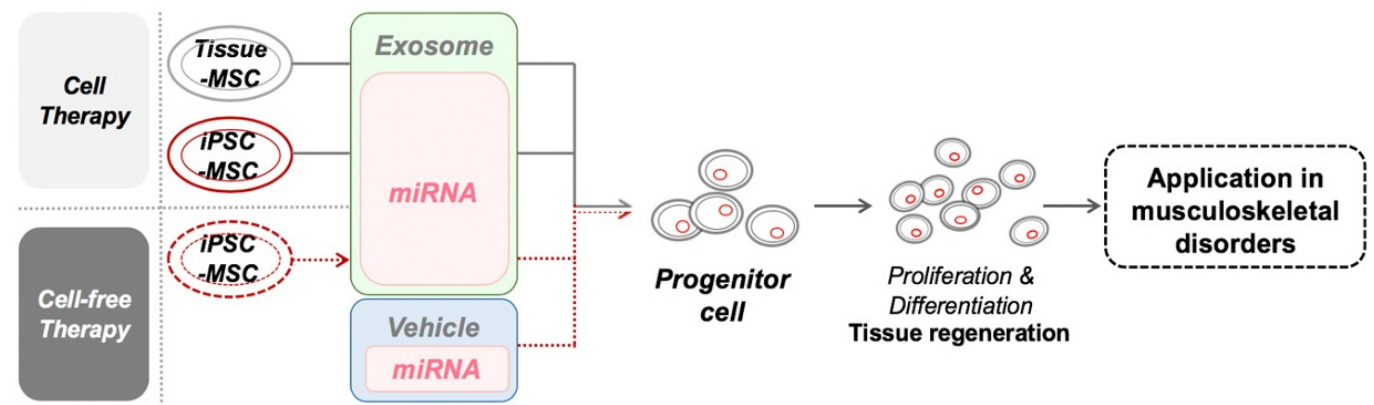

Fig. 3. Schematic diagram of cell therapy and cell-free therapy. The schematic diagram demonstrating the cell-therapy and cell-free therapy for musculoskeletal disorders. For cell therapy, tissue-derived MSCs and iPSC-MSCs are applied by direct injection into injured area. A part of injected cells migrates to the damaged region of tissue and participates in proliferation and differentiation while most of the injected cells secrete paracrine factors such as exosomes containing miRNAs to promote a regenerative condition. Cell-free therapy includes exosome therapy and miRNA therapy. Exosome can be obtained in massive quantity from iPSC-MSCs, and synthetic miRNA also can be obtained in vitro.

tations regarding the difficulty of isolation and purification of miRNA as a clinical setting to patients, which requires sufficient amounts and, specifically, remains a significant challenge (166), as high quantity is imperative for therapy. Therefore, except for other factors secreted from MSCs, only therapeutic effect of miRNA will become clear, and if specific miRNAs are selected, safe treatment will be possible without cells. But in severe conditions or in old patients whose regeneration ability of cell is depreciated, non-cell therapy is not the best choice. Patients with advanced aging or severe diseases need to be replenished with healthy cells so that the cells can function in the injured site by homing and paracrine secretion. We recommend iPSC-MSCs therapy that can provide healthy cells, and furthermore, look forward to a future where selective treatment can be made between non-cell therapy (miRNA therapy) and cell therapy depending on the patient's condition. Ultimately, final goal for clinic is to gain sufficient amounts of iPSC-MSCs that could yield as many miRNAs desired to develop safe and efficacious therapeutic agents, now that studies have demonstrated that this approach reduces immune rejection, enhance therapeutic effects on musculoskeletal disorders, and renders patients' safety (Fig. 3).

\section{Acknowledgments}

This work was supported by a grant from Kyungpook National University Development Project Research Fund, 2018, and the National Research Foundation of Korea (NRF) (2017R1E1A1AO1072781) by the Korean Government.

\section{Potential Conflict of Interest}

The authors have no conflicting financial interest.

\section{References}

1. Bongers PM, de Winter CR, Kompier MA, Hildebrandt VH. Psychosocial factors at work and musculoskeletal disease. Scand J Work Environ Health 1993;19:297-312

2. Barbe MF, Gallagher S, Massicotte VS, Tytell M, Popoff $\mathrm{SN}$, Barr-Gillespie AE. The interaction of force and repetition on musculoskeletal and neural tissue responses and sensorimotor behavior in a rat model of work-related musculoskeletal disorders. BMC Musculoskelet Disord 2013;14: 303

3. Bianco P, Robey PG, Simmons PJ. Mesenchymal stem cells: revisiting history, concepts, and assays. Cell Stem Cell 2008;2:313-319

4. Lu D, Chen B, Liang Z, Deng W, Jiang Y, Li S, Xu J, Wu Q, Zhang Z, Xie B, Chen S. Comparison of bone marrow mesenchymal stem cells with bone marrow-derived mononuclear cells for treatment of diabetic critical limb ischemia and foot ulcer: a double-blind, randomized, controlled trial. Diabetes Res Clin Pract 2011;92:26-36

5. Yamada Y, Ueda M, Hibi H, Baba S. A novel approach to periodontal tissue regeneration with mesenchymal stem cells and platelet-rich plasma using tissue engineering technology: a clinical case report. Int J Periodontics Restorative Dent 2006;26:363-369

6. Böcker W, Yin Z, Drosse I, Haasters F, Rossmann O, Wierer M, Popov C, Locher M, Mutschler W, Docheva D, Schieker M. Introducing a single-cell-derived human mesenchymal stem cell line expressing hTERT after lentiviral gene transfer. J Cell Mol Med 2008;12:1347-1359

7. Stolzing A, Jones E, McGonagle D, Scutt A. Age-related changes in human bone marrow-derived mesenchymal stem cells: consequences for cell therapies. Mech Ageing Dev 2008;129:163-173

8. Zhou S, Greenberger JS, Epperly MW, Goff JP, Adler C, Leboff MS, Glowacki J. Age-related intrinsic changes in human bone-marrow-derived mesenchymal stem cells and their differentiation to osteoblasts. Aging Cell 2008;7:335- 
343

9. Whitworth DJ, Banks TA. Stem cell therapies for treating osteoarthritis: prescient or premature? Vet J 2014;202:416424

10. Chung MJ, Park S, Son JY, Lee JY, Yun HH, Lee EJ, Lee EM, Cho GJ, Lee S, Park HS, Jeong KS. Differentiation of equine induced pluripotent stem cells into mesenchymal lineage for therapeutic use. Cell Cycle 2019;18:2954-2971

11. Lian Q, Zhang Y, Zhang J, Zhang HK, Wu X, Zhang Y, Lam FF, Kang S, Xia JC, Lai WH, Au KW, Chow YY, Siu CW, Lee CN, Tse HF. Functional mesenchymal stem cells derived from human induced pluripotent stem cells attenuate limb ischemia in mice. Circulation 2010;121:1113-1123

12. Mehta G, Shiozawa Y, Taichman R. Hematopoietic stem cells and their niches. In: Ma P, editor. Biomaterials and Regenerative Medicine. Cambridge: Cambridge University Press; 2014. 44-63

13. Wang W, Zhang E, Lin C. MicroRNAs in tumor angiogenesis. Life Sci 2015;136:28-35

14. Calin GA, Croce CM. MicroRNA signatures in human cancers. Nat Rev Cancer 2006;6:857-866

15. Martello G, Rosato A, Ferrari F, Manfrin A, Cordenonsi M, Dupont S, Enzo E, Guzzardo V, Rondina M, Spruce T, Parenti AR, Daidone MG, Bicciato S, Piccolo S. A microRNA targeting dicer for metastasis control. Cell 2010;141:11951207

16. Xie T, Huang $M$, Wang $Y$, Wang L, Chen C, Chu X. MicroRNAs as regulators, biomarkers and therapeutic targets in the drug resistance of colorectal cancer. Cell Physiol Biochem 2016;40:62-76

17. Ambros V. The functions of animal microRNAs. Nature 2004;431:350-355

18. Bartel DP. MicroRNAs: genomics, biogenesis, mechanism, and function. Cell 2004;116:281-297

19. Bartel DP. Metazoan microRNAs. Cell 2018;173:20-51

20. van Niel G, D'Angelo G, Raposo G. Shedding light on the cell biology of extracellular vesicles. Nat Rev Mol Cell Biol 2018;19:213-228

21. Phan J, Kumar P, Hao D, Gao K, Farmer D, Wang A. Engineering mesenchymal stem cells to improve their exosome efficacy and yield for cell-free therapy. J Extracell Vesicles 2018;7:1522236

22. Rani S, Ryan AE, Griffin MD, Ritter T. Mesenchymal stem cell-derived extracellular vesicles: toward cell-free therapeutic applications. Mol Ther 2015;23:812-823

23. Pinheiro A, Silva AM, Teixeira JH, Gonçalves RM, Almeida MI, Barbosa MA, Santos SG. Extracellular vesicles: intelligent delivery strategies for therapeutic applications. J Control Release 2018;289:56-69

24. Lo Cicero A, Stahl PD, Raposo G. Extracellular vesicles shuffling intercellular messages: for good or for bad. Curr Opin Cell Biol 2015;35:69-77

25. Chu DT, Phuong TNT, Tien NLB, Tran DK, Thanh VV, Quang TL, Truong DT, Pham VH, Ngoc VTN, Chu-Dinh $\mathrm{T}$, Kushekhar K. An update on the progress of isolation, culture, storage, and clinical application of human bone marrow mesenchymal stem/stromal cells. Int J Mol Sci 2020;21:708

26. Bunnell BA, Flaat M, Gagliardi C, Patel B, Ripoll C. Adipose-derived stem cells: isolation, expansion and differentiation. Methods 2008;45:115-120

27. Mazini L, Rochette L, Amine M, Malka G. Regenerative capacity of adipose derived stem cells (ADSCs), comparison with mesenchymal stem cells (MSCs). Int J Mol Sci 2019;20:2523

28. Duckers HJ, Pinkernell K, Milstein AM, Hedrick MH. The Bedside Celution system for isolation of adipose derived regenerative cells. EuroIntervention 2006;2:395-398

29. Coleman SR. Structural fat grafting: more than a permanent filler. Plast Reconstr Surg 2006;118(3 Suppl):108S$120 \mathrm{~S}$

30. Van RL, Roncari DA. Isolation of fat cell precursors from adult rat adipose tissue. Cell Tissue Res 1977;181:197-203

31. Li CY, Wu XY, Tong JB, Yang XX, Zhao JL, Zheng QF, Zhao GB, Ma ZJ. Comparative analysis of human mesenchymal stem cells from bone marrow and adipose tissue under xeno-free conditions for cell therapy. Stem Cell Res Ther 2015;6:55

32. Sakaguchi Y, Sekiya I, Yagishita K, Muneta T. Comparison of human stem cells derived from various mesenchymal tissues: superiority of synovium as a cell source. Arthritis Rheum 2005;52:2521-2529

33. Fan J, Varshney RR, Ren L, Cai D, Wang DA. Synoviumderived mesenchymal stem cells: a new cell source for musculoskeletal regeneration. Tissue Eng Part B Rev 2009;15: 75-86

34. To K, Zhang B, Romain K, Mak C, Khan W. Synovium-derived mesenchymal stem cell transplantation in cartilage regeneration: a PRISMA review of in vivo studies. Front Bioeng Biotechnol 2019;7:314

35. Wang $M$, Yang $Y$, Yang D, Luo F, Liang W, Guo S, Xu J. The immunomodulatory activity of human umbilical cord blood-derived mesenchymal stem cells in vitro. Immunology 2009;126:220-232

36. Wobus AM, Boheler KR. Embryonic stem cells: prospects for developmental biology and cell therapy. Physiol Rev 2005;85:635-678

37. Mitsui K, Tokuzawa Y, Itoh H, Segawa K, Murakami M, Takahashi K, Maruyama M, Maeda M, Yamanaka S. The homeoprotein Nanog is required for maintenance of pluripotency in mouse epiblast and ES cells. Cell 2003;113:631642

38. Takahashi K, Yamanaka S. Induction of pluripotent stem cells from mouse embryonic and adult fibroblast cultures by defined factors. Cell 2006;126:663-676

39. Takahashi K, Tanabe K, Ohnuki M, Narita M, Ichisaka T, Tomoda K, Yamanaka S. Induction of pluripotent stem cells from adult human fibroblasts by defined factors. Cell 2007;131:861-872

40. Nakagawa $M$, Koyanagi $M$, Tanabe $K$, Takahashi K, Ichisaka T, Aoi T, Okita K, Mochiduki Y, Takizawa N, Yamanaka S. Generation of induced pluripotent stem cells 
without Myc from mouse and human fibroblasts. Nat Biotechnol 2008;26:101-106

41. Montserrat N, Ramírez-Bajo MJ, Xia Y, Sancho-Martinez I, Moya-Rull D, Miquel-Serra L, Yang S, Nivet E, Cortina C, González F, Izpisua Belmonte JC, Campistol JM. Generation of induced pluripotent stem cells from human renal proximal tubular cells with only two transcription factors, OCT4 and SOX2. J Biol Chem 2012;287:2413124138

42. Lam MT, Longaker MT. Comparison of several attachment methods for human iPS, embryonic and adipose-derived stem cells for tissue engineering. J Tissue Eng Regen Med 2012;6 Suppl 3:s80-s86

43. Volarevic V, Markovic BS, Gazdic M, Volarevic A, Jovicic $\mathrm{N}$, Arsenijevic N, Armstrong L, Djonov V, Lako M, Stojkovic M. Ethical and safety issues of stem cell-based therapy. Int J Med Sci 2018;15:36-45

44. Khan MA, Alanazi F, Ahmed HA, Shamma T, Kelly K, Hammad MA, Alawad AO, Assiri AM, Broering DC. iPSC-derived MSC therapy induces immune tolerance and supports long-term graft survival in mouse orthotopic tracheal transplants. Stem Cell Res Ther 2019;10:290

45. Zhang J, Chan YC, Ho JC, Siu CW, Lian Q, Tse HF. Regulation of cell proliferation of human induced pluripotent stem cell-derived mesenchymal stem cells via etherà-go-go 1 (hEAG1) potassium channel. Am J Physiol Cell Physiol 2012;303:C115-C125

46. Meng X, Su RJ, Baylink DJ, Neises A, Kiroyan JB, Lee WY, Payne KJ, Gridley DS, Wang J, Lau KH, Li G, Zhang $\mathrm{XB}$. Rapid and efficient reprogramming of human fetal and adult blood $\mathrm{CD} 34^{+}$cells into mesenchymal stem cells with a single factor. Cell Res 2013;23:658-672

47. Chen W, Baylink DJ, Lau KH, Zhang XB. Generation of mesenchymal stem cells by blood cell reprogramming. Curr Stem Cell Res Ther 2016;11:114-121

48. Lee EJ, Kim M, Kim YD, Chung MJ, Elfadl A, Ulah HMA, Park D, Lee S, Park HS, Kim TH, Hwang D, Jeong KS. Establishment of stably expandable induced myogenic stem cells by four transcription factors. Cell Death Dis 2018;9: 1092

49. Steens J, Klein D. Current strategies to generate human mesenchymal stem cells in vitro. Stem Cells Int 2018;2018: 6726185

50. Huang CP, Chen CC, Shyr CR. Xenogeneic cell therapy provides a novel potential therapeutic option for cancers by restoring tissue function, repairing cancer wound and reviving anti-tumor immune responses. Cancer Cell Int 2018; 18:9

51. Liew A, O'Brien T. Therapeutic potential for mesenchymal stem cell transplantation in critical limb ischemia. Stem Cell Res Ther 2012;3:28

52. Obaid H, Connell D. Cell therapy in tendon disorders: what is the current evidence? Am J Sports Med 2010;38: 2123-2132

53. Yin Z, Chen X, Chen JL, Ouyang HW. Stem cells for tendon tissue engineering and regeneration. Expert Opin Biol
Ther 2010;10:689-700

54. Fong EL, Chan CK, Goodman SB. Stem cell homing in musculoskeletal injury. Biomaterials 2011;32:395-409

55. Diekman BO, Wu CL, Louer CR, Furman BD, Huebner JL, Kraus VB, Olson SA, Guilak F. Intra-articular delivery of purified mesenchymal stem cells from C57BL/6 or MRL/ $\mathrm{MpJ}$ superhealer mice prevents posttraumatic arthritis. Cell Transplant 2013;22:1395-1408

56. Huang TF, Yew TL, Chiang ER, Ma HL, Hsu CY, Hsu SH, Hsu YT, Hung SC. Mesenchymal stem cells from a hypoxic culture improve and engraft Achilles tendon repair. Am J Sports Med 2013;41:1117-1125

57. Okamoto N, Kushida T, Oe K, Umeda M, Ikehara S, Iida $\mathrm{H}$. Treating Achilles tendon rupture in rats with bone-marrow-cell transplantation therapy. J Bone Joint Surg Am 2010;92:2776-2284

58. Nourissat G, Diop A, Maurel N, Salvat C, Dumont S, Pigenet A, Gosset M, Houard X, Berenbaum F. Mesenchymal stem cell therapy regenerates the native bone-tendon junction after surgical repair in a degenerative rat model. PLoS One 2010;5:e12248

59. Suhaeb AM, Naveen S, Mansor A, Kamarul T. Hyaluronic acid with or without bone marrow derived-mesenchymal stem cells improves osteoarthritic knee changes in rat model: a preliminary report. Indian J Exp Biol 2012;50:383-390

60. Gupta PK, Chullikana A, Rengasamy M, Shetty N, Pandey V, Agarwal V, Wagh SY, Vellotare PK, Damodaran D, Viswanathan P, Thej C, Balasubramanian S, Majumdar AS. Efficacy and safety of adult human bone marrow-derived, cultured, pooled, allogeneic mesenchymal stromal cells $\left(\right.$ Stempeucel ${ }^{\circledR}$ ): preclinical and clinical trial in osteoarthritis of the knee joint. Arthritis Res Ther 2016;18:301

61. Sato M, Uchida K, Nakajima H, Miyazaki T, Guerrero AR, Watanabe S, Roberts S, Baba H. Direct transplantation of mesenchymal stem cells into the knee joints of Hartley strain guinea pigs with spontaneous osteoarthritis. Arthritis Res Ther 2012;14:R31

62. Kim SS, Kang MS, Lee KY, Lee MJ, Wang L, Kim HJ. Therapeutic effects of mesenchymal stem cells and hyaluronic acid injection on osteochondral defects in rabbits' knees. Knee Surg Relat Res 2012;24:164-172

63. Chiang ER, Ma HL, Wang JP, Liu CL, Chen TH, Hung SC. Allogeneic mesenchymal stem cells in combination with hyaluronic acid for the treatment of osteoarthritis in rabbits. PLoS One 2016;11:e0149835

64. Yang Q, Peng J, Lu SB, Guo QY, Zhao B, Zhang L, Wang $\mathrm{AY}, \mathrm{Xu}$ WJ, Xia Q, Ma XL, Hu YC, Xu BS. Evaluation of an extracellular matrix-derived acellular biphasic scaffold/cell construct in the repair of a large articular highload-bearing osteochondral defect in a canine model. Chin Med J (Engl) 2011;124:3930-3938

65. McIlwraith CW, Frisbie DD, Rodkey WG, Kisiday JD, Werpy NM, Kawcak CE, Steadman JR. Evaluation of intra-articular mesenchymal stem cells to augment healing of microfractured chondral defects. Arthroscopy 2011;27:15521561 
66. Al Faqeh H, Nor Hamdan BM, Chen HC, Aminuddin BS, Ruszymah BH. The potential of intra-articular injection of chondrogenic-induced bone marrow stem cells to retard the progression of osteoarthritis in a sheep model. Exp Gerontol 2012;47:458-464

67. Smith RK, Werling NJ, Dakin SG, Alam R, Goodship AE, Dudhia J. Beneficial effects of autologous bone marrow-derived mesenchymal stem cells in naturally occurring tendinopathy. PLoS One 2013;8:e75697

68. Godwin EE, Young NJ, Dudhia J, Beamish IC, Smith RK. Implantation of bone marrow-derived mesenchymal stem cells demonstrates improved outcome in horses with overstrain injury of the superficial digital flexor tendon. Equine Vet J 2012;44:25-32

69. Caniglia CJ, Schramme MC, Smith RK. The effect of intralesional injection of bone marrow derived mesenchymal stem cells and bone marrow supernatant on collagen fibril size in a surgical model of equine superficial digital flexor tendonitis. Equine Vet J 2012;44:587-593

70. Seo JP, Tanabe T, Tsuzuki N, Haneda S, Yamada K, Furuoka H, Tabata Y, Sasaki N. Effects of bilayer gelatin/ $\beta$-tricalcium phosphate sponges loaded with mesenchymal stem cells, chondrocytes, bone morphogenetic protein-2, and platelet rich plasma on osteochondral defects of the talus in horses. Res Vet Sci 2013;95:1210-1216

71. Lamo-Espinosa JM, Mora G, Blanco JF, Granero-Moltó F, Nuñez-Córdoba JM, Sánchez-Echenique C, Bondía JM, Aquerreta JD, Andreu EJ, Ornilla E, Villarón EM, ValentíAzcárate A, Sánchez-Guijo F, Del Cañizo MC, Valentí-Nin JR, Prósper F. Intra-articular injection of two different doses of autologous bone marrow mesenchymal stem cells versus hyaluronic acid in the treatment of knee osteoarthritis: multicenter randomized controlled clinical trial (phase I/II). J Transl Med 2016;14:246

72. Lamo-Espinosa JM, Mora G, Blanco JF, Granero-Moltó F, Núñez-Córdoba JM, López-Elío S, Andreu E, SánchezGuijo F, Aquerreta JD, Bondía JM, Valentí-Azcárate A, Del Consuelo Del Cañizo M, Villarón EM, Valentí-Nin JR, Prósper F. Intra-articular injection of two different doses of autologous bone marrow mesenchymal stem cells versus hyaluronic acid in the treatment of knee osteoarthritis: long-term follow up of a multicenter randomized controlled clinical trial (phase I/II). J Transl Med 2018;16:213

73. Vangsness CT Jr, Farr J 2nd, Boyd J, Dellaero DT, Mills $\mathrm{CR}$, LeRoux-Williams M. Adult human mesenchymal stem cells delivered via intra-articular injection to the knee following partial medial meniscectomy: a randomized, double-blind, controlled study. J Bone Joint Surg Am 2014;96: 90-98

74. Vega A, Martín-Ferrero MA, Del Canto F, Alberca M, García V, Munar A, Orozco L, Soler R, Fuertes JJ, Huguet M, Sánchez A, García-Sancho J. Treatment of knee osteoarthritis with allogeneic bone marrow mesenchymal stem cells: a randomized controlled trial. Transplantation 2015; 99:1681-1690

75. Al-Najar M, Khalil H, Al-Ajlouni J, Al-Antary E, Hamdan
M, Rahmeh R, Alhattab D, Samara O, Yasin M, Abdullah AA, Al-Jabbari E, Hmaid D, Jafar H, Awidi A. Intra-articular injection of expanded autologous bone marrow mesenchymal cells in moderate and severe knee osteoarthritis is safe: a phase I/II study. J Orthop Surg Res 2017;12:190

76. Emadedin M, Aghdami N, Taghiyar L, Fazeli R, Moghadasali R, Jahangir S, Farjad R, Baghaban Eslaminejad $M$. Intra-articular injection of autologous mesenchymal stem cells in six patients with knee osteoarthritis. Arch Iran Med 2012;15:422-428

77. Soler RR, Munar A, Soler RF, Peirau X, Huguet M, Alberca M, Sánchez A, García SJ, Orozco L. Treatment of knee osteoarthritis with autologous expanded bone marrow mesenchymal stem cells: 50 cases clinical and MRI results at one year follow-up. J Stem Cell Res Ther 2015;5:6

78. Soler R, Orozco L, Munar A, Huguet M, López R, Vives J, Coll R, Codinach M, Garcia-Lopez J. Final results of a phase I-II trial using ex vivo expanded autologous Mesenchymal Stromal Cells for the treatment of osteoarthritis of the knee confirming safety and suggesting cartilage regeneration. Knee 2016;23:647-654

79. Mehrabani D, Mojtahed Jaberi F, Zakerinia M, Hadianfard MJ, Jalli R, Tanideh N, Zare S. The healing effect of bone marrow-derived stem cells in knee osteoarthritis: a case report. World J Plast Surg 2016;5:168-174

80. Davatchi F, Abdollahi BS, Mohyeddin M, Shahram F, Nikbin B. Mesenchymal stem cell therapy for knee osteoarthritis. Preliminary report of four patients. Int J Rheum Dis 2011;14:211-215

81. Orozco L, Munar A, Soler R, Alberca M, Soler F, Huguet M, Sentís J, Sánchez A, García-Sancho J. Treatment of knee osteoarthritis with autologous mesenchymal stem cells: a pilot study. Transplantation 2013;95:1535-1541

82. Toghraie FS, Chenari N, Gholipour MA, Faghih Z, Torabinejad S, Dehghani S, Ghaderi A. Treatment of osteoarthritis with infrapatellar fat pad derived mesenchymal stem cells in rabbit. Knee 2011;18:71-75

83. Zaragoza MR, Serrato BC, Poveda JMC, Juncosa JJS, Bertomeu RC, Balletbo MG, Fariña MM, Guereño JMV. Force platform analysis of the effect of intrarticular injection of autologous adipose-derived mesenchymal stem cells associated to PRGF in osteoarthritic dogs. Osteoarthr Cartil 2014;22 Suppl:S198-S199

84. Forcales SV. Potential of adipose-derived stem cells in muscular regenerative therapies. Front Aging Neurosci 2015;7:123

85. Lee EM, Kim AY, Lee EJ, Park JK, Lee MM, Hwang M, Kim CY, Kim SY, Jeong KS. Therapeutic effects of mouse adipose-derived stem cells and losartan in the skeletal muscle of injured mdx mice. Cell Transplant 2015;24:939-953

86. Song Y, Du H, Dai C, Zhang L, Li S, Hunter DJ, Lu L, Bao C. Human adipose-derived mesenchymal stem cells for osteoarthritis: a pilot study with long-term follow-up and repeated injections. Regen Med 2018;13:295-307

87. Lu L, Dai C, Zhang Z, Du H, Li S, Ye P, Fu Q, Zhang L, Wu X, Dong Y, Song Y, Zhao D, Pang Y, Bao C. Treatment 
of knee osteoarthritis with intra-articular injection of autologous adipose-derived mesenchymal progenitor cells: a prospective, randomized, double-blind, active-controlled, phase IIb clinical trial. Stem Cell Res Ther 2019;10:143

88. Zhao X, Ruan J, Tang H, Li J, Shi Y, Li M, Li S, Xu C, Lu Q, Dai C. Multi-compositional MRI evaluation of repair cartilage in knee osteoarthritis with treatment of allogeneic human adipose-derived mesenchymal progenitor cells. Stem Cell Res Ther 2019;10:308

89. Lee JC, Min HJ, Park HJ, Lee S, Seong SC, Lee MC. Synovial membrane-derived mesenchymal stem cells supported by platelet-rich plasma can repair osteochondral defects in a rabbit model. Arthroscopy 2013;29:1034-1046

90. Shimomura K, Moriguchi Y, Ando W, Nansai R, Fujie H, Hart DA, Gobbi A, Kita K, Horibe S, Shino K, Yoshikawa H, Nakamura N. Osteochondral repair using a scaffold-free tissue-engineered construct derived from synovial mesenchymal stem cells and a hydroxyapatite-based artificial bone. Tissue Eng Part A 2014;20:2291-2304

91. Shimomura K, Ando W, Tateishi K, Nansai R, Fujie H, Hart DA, Kohda H, Kita K, Kanamoto T, Mae T, Nakata K, Shino K, Yoshikawa H, Nakamura N. The influence of skeletal maturity on allogenic synovial mesenchymal stem cell-based repair of cartilage in a large animal model. Biomaterials 2010;31:8004-8011

92. Nakamura T, Sekiya I, Muneta T, Kobayashi E. [Articular cartilage regenerative therapy with synovial mesenchymal stem cells in a pig model]. Clin Calcium 2013;23:1741-1749 Japanese.

93. Carrade DD, Owens SD, Galuppo LD, Vidal MA, Ferraro GL, Librach F, Buerchler S, Friedman MS, Walker NJ, Borjesson DL. Clinicopathologic findings following intra-articular injection of autologous and allogeneic placentally derived equine mesenchymal stem cells in horses. Cytotherapy 2011;13:419-430

94. Van Loon VJ, Scheffer CJ, Genn HJ, Hoogendoorn AC, Greve JW. Clinical follow-up of horses treated with allogeneic equine mesenchymal stem cells derived from umbilical cord blood for different tendon and ligament disorders. Vet Q 2014;34:92-97

95. Jeong SY, Kim DH, Ha J, Jin HJ, Kwon SJ, Chang JW, Choi SJ, Oh W, Yang YS, Kim G, Kim JS, Yoon JR, Cho DH, Jeon HB. Thrombospondin-2 secreted by human umbilical cord blood-derived mesenchymal stem cells promotes chondrogenic differentiation. Stem Cells 2013;31: 2136-2148

96. Kwon DR, Park GY, Lee SC. Regenerative effects of mesenchymal stem cells by dosage in a chronic rotator cuff tendon tear in a rabbit model. Regen Med 2019;14:1001-1012

97. An JH, Park H, Song JA, Ki KH, Yang JY, Choi HJ, Cho SW, Kim SW, Kim SY, Yoo JJ, Baek WY, Kim JE, Choi SJ, Oh W, Shin CS. Transplantation of human umbilical cord blood-derived mesenchymal stem cells or their conditioned medium prevents bone loss in ovariectomized nude mice. Tissue Eng Part A 2013;19:685-696

98. Song JS, Hong KT, Kim NM, Jung JY, Park HS, Lee SH,
Cho YJ, Kim SJ. Implantation of allogenic umbilical cord blood-derived mesenchymal stem cells improves knee osteoarthritis outcomes: two-year follow-up. Regen Ther 2020; 14:32-39

99. Jung Y, Bauer G, Nolta JA. Concise review: induced pluripotent stem cell-derived mesenchymal stem cells: progress toward safe clinical products. Stem Cells 2012;30:42-47

100. Jungbluth P, Spitzhorn LS, Grassmann J, Tanner S, Latz D, Rahman MS, Bohndorf M, Wruck W, Sager M, Grotheer V, Kröpil P, Hakimi M, Windolf J, Schneppendahl J, Adjaye J. Human iPSC-derived iMSCs improve bone regeneration in mini-pigs. Bone Res 2019;7:32

101. Lin L, Bolund L, Luo Y. Towards personalized regenerative cell therapy: mesenchymal stem cells derived from human induced pluripotent stem cells. Curr Stem Cell Res Ther 2016;11:122-130

102. Kim IG, Park SA, Lee SH, Choi JS, Cho H, Lee SJ, Kwon YW, Kwon SK. Transplantation of a 3D-printed tracheal graft combined with iPS cell-derived MSCs and chondrocytes. Sci Rep 2020;10:4326

103. Chacón-Martínez CA, Koester J, Wickström SA. Signaling in the stem cell niche: regulating cell fate, function and plasticity. Development 2018;145:dev165399

104. Park JK, Ki MR, Lee EM, Kim AY, You SY, Han SY, Lee EJ, Hong IH, Kwon SH, Kim SJ, Rando TA, Jeong KS. Losartan improves adipose tissue-derived stem cell niche by inhibiting transforming growth factor- $\beta$ and fibrosis in skeletal muscle injury. Cell Transplant 2012;21:2407-2424

105. Shcherbata HR. miRNA functions in stem cells and their niches: lessons from the Drosophila ovary. Curr Opin Insect Sci 2019;31:29-36

106. Sims PJ, Faioni EM, Wiedmer T, Shattil SJ. Complement proteins C5b-9 cause release of membrane vesicles from the platelet surface that are enriched in the membrane receptor for coagulation factor $\mathrm{Va}$ and express prothrombinase activity. J Biol Chem 1988;263:18205-18212

107. Satta N, Toti F, Feugeas O, Bohbot A, Dachary-Prigent J, Eschwège V, Hedman $\mathrm{H}$, Freyssinet JM. Monocyte vesiculation is a possible mechanism for dissemination of membrane-associated procoagulant activities and adhesion molecules after stimulation by lipopolysaccharide. J Immunol 1994;153:3245-3255

108. Tricarico C, Clancy J, D'Souza-Schorey C. Biology and biogenesis of shed microvesicles. Small GTPases 2017;8:220232

109. Pan BT, Teng K, Wu C, Adam M, Johnstone RM. Electron microscopic evidence for externalization of the transferrin receptor in vesicular form in sheep reticulocytes. J Cell Biol 1985;101:942-948

110. Meirelles Lda S, Fontes AM, Covas DT, Caplan AI. Mechanisms involved in the therapeutic properties of mesenchymal stem cells. Cytokine Growth Factor Rev 2009;20: 419-427

111. Deng H, Sun C, Sun Y, Li H, Yang L, Wu D, Gao Q, Jiang $\mathrm{X}$. Lipid, protein, and microRNA composition within mesenchymal stem cell-derived exosomes. Cell Reprogram 


\section{8;20:178-186}

112. Choi DS, Kim DK, Kim YK, Gho YS. Proteomics, transcriptomics and lipidomics of exosomes and ectosomes. Proteomics 2013;13:1554-1571

113. Choi DS, Kim DK, Kim YK, Gho YS. Proteomics of extracellular vesicles: exosomes and ectosomes. Mass Spectrom Rev 2015;34:474-490

114. Mathivanan S, Simpson RJ. ExoCarta: a compendium of exosomal proteins and RNA. Proteomics 2009;9:4997-5000

115. Ling H, Fabbri M, Calin GA. MicroRNAs and other noncoding RNAs as targets for anticancer drug development. Nat Rev Drug Discov 2013;12:847-865

116. Xin H, Li Y, Chopp M. Exosomes/miRNAs as mediating cell-based therapy of stroke. Front Cell Neurosci 2014;8:377

117. EL Andaloussi S, Mäger I, Breakefield XO, Wood MJ. Extracellular vesicles: biology and emerging therapeutic opportunities. Nat Rev Drug Discov 2013;12:347-357

118. Feng Y, Huang W, Wani M, Yu X, Ashraf M. Ischemic preconditioning potentiates the protective effect of stem cells through secretion of exosomes by targeting Mecp2 via miR22. PLoS One 2014;9:e88685

119. Furuta T, Miyaki S, Ishitobi H, Ogura T, Kato Y, Kamei N, Miyado K, Higashi Y, Ochi M. Mesenchymal stem cellderived exosomes promote fracture healing in a mouse model. Stem Cells Transl Med 2016;5:1620-1630

120. Nakamura Y, Miyaki S, Ishitobi H, Matsuyama S, Nakasa T, Kamei N, Akimoto T, Higashi Y, Ochi M. Mesenchymalstem-cell-derived exosomes accelerate skeletal muscle regeneration. FEBS Lett 2015;589:1257-1265

121. Liu X, Yang Y, Li Y, Niu X, Zhao B, Wang Y, Bao C, Xie $\mathrm{Z}$, Lin $\mathrm{Q}, \mathrm{Zhu} \mathrm{L}$. Integration of stem cell-derived exosomes with in situ hydrogel glue as a promising tissue patch for articular cartilage regeneration. Nanoscale 2017;9:44304438

122. Qi X, Zhang J, Yuan H, Xu Z, Li Q, Niu X, Hu B, Wang Y, Li X. Exosomes secreted by human-induced pluripotent stem cell-derived mesenchymal stem cells repair criticalsized bone defects through enhanced angiogenesis and osteogenesis in osteoporotic rats. Int J Biol Sci 2016;12:836849

123. Hu GW, Li Q, Niu X, Hu B, Liu J, Zhou SM, Guo SC, Lang HL, Zhang CQ, Wang Y, Deng ZF. Exosomes secreted by human-induced pluripotent stem cell-derived mesenchymal stem cells attenuate limb ischemia by promoting angiogenesis in mice. Stem Cell Res Ther 2015;6:10

124. Liu X, Li Q, Niu X, Hu B, Chen S, Song W, Ding J, Zhang C, Wang Y. Exosomes secreted from human-induced pluripotent stem cell-derived mesenchymal stem cells prevent osteonecrosis of the femoral head by promoting angiogenesis. Int J Biol Sci 2017;13:232-244

125. Zhu Y, Wang Y, Zhao B, Niu X, Hu B, Li Q, Zhang J, Ding J, Chen Y, Wang Y. Comparison of exosomes secreted by induced pluripotent stem cell-derived mesenchymal stem cells and synovial membrane-derived mesenchymal stem cells for the treatment of osteoarthritis. Stem Cell Res Ther 2017;8:64
126. Sabapathy V, Kumar S. hiPSC-derived iMSCs: NextGen MSCs as an advanced therapeutically active cell resource for regenerative medicine. J Cell Mol Med 2016;20:15711588

127. Zhang Y, Liang X, Liao S, Wang W, Wang J, Li X, Ding Y, Liang Y, Gao F, Yang M, Fu Q, Xu A, Chai YH, He J, Tse HF, Lian Q. Potent paracrine effects of human induced pluripotent stem cell-derived mesenchymal stem cells attenuate doxorubicin-induced cardiomyopathy. Sci Rep 2015;5:11235

128. Katsuda T, Tsuchiya R, Kosaka N, Yoshioka Y, Takagaki K, Oki K, Takeshita F, Sakai Y, Kuroda M, Ochiya T. Human adipose tissue-derived mesenchymal stem cells secrete functional neprilysin-bound exosomes. Sci Rep 2013; 3:1197

129. Del Fattore A, Luciano R, Saracino R, Battafarano G, Rizzo C, Pascucci L, Alessandri G, Pessina A, Perrotta A, Fierabracci A, Muraca M. Differential effects of extracellular vesicles secreted by mesenchymal stem cells from different sources on glioblastoma cells. Expert Opin Biol Ther 2015; 15:495-504

130. Lopez-Verrilli MA, Caviedes A, Cabrera A, Sandoval S, Wyneken U, Khoury M. Mesenchymal stem cell-derived exosomes from different sources selectively promote neuritic outgrowth. Neuroscience 2016;320:129-139

131. Christopher AF, Kaur RP, Kaur G, Kaur A, Gupta V, Bansal P. MicroRNA therapeutics: discovering novel targets and developing specific therapy. Perspect Clin Res 2016;7:68-74

132. Johnnidis JB, Harris $\mathrm{MH}$, Wheeler RT, Stehling-Sun S, Lam MH, Kirak O, Brummelkamp TR, Fleming MD, Camargo FD. Regulation of progenitor cell proliferation and granulocyte function by microRNA-223. Nature 2008; 451:1125-1129

133. Sun L, Wu Z, Shao Y, Pu Y, Miu W, Yao J, Wu Y, Yang Z. MicroRNA-34a suppresses cell proliferation and induces apoptosis in U87 glioma stem cells. Technol Cancer Res Treat 2012;11:483-490

134. Anderson RM. A role for dicer in aging and stress survival. Cell Metab 2012;16:285-286

135. Höbel S, Aigner A. Polyethylenimines for siRNA and miRNA delivery in vivo. Wiley Interdiscip Rev Nanomed Nanobiotechnol 2013;5:484-501

136. Fasanaro P, Greco S, Ivan M, Capogrossi MC, Martelli F. microRNA: emerging therapeutic targets in acute ischemic diseases. Pharmacol Ther 2010;125:92-104

137. Pereira DM, Rodrigues PM, Borralho PM, Rodrigues CM. Delivering the promise of miRNA cancer therapeutics. Drug Discov Today 2013;18:282-289

138. Lv H, Zhang S, Wang B, Cui S, Yan J. Toxicity of cationic lipids and cationic polymers in gene delivery. J Control Release 2006;114:100-109

139. Zhang Y, Wang Z, Gemeinhart RA. Progress in microRNA delivery. J Control Release 2013;172:962-974

140. Lee SY, Huh MS, Lee S, Lee SJ, Chung H, Park JH, Oh YK, Choi K, Kim K, Kwon IC. Stability and cellular uptake 
of polymerized siRNA (poly-siRNA)/polyethylenimine (PEI) complexes for efficient gene silencing. J Control Release 2010;141:339-346

141. Lee SWL, Paoletti C, Campisi M, Osaki T, Adriani G, Kamm RD, Mattu C, Chiono V. MicroRNA delivery through nanoparticles. J Control Release 2019;313:80-95

142. Álvarez-Viejo M. Mesenchymal stem cells from different sources and their derived exosomes: a pre-clinical perspective. World J Stem Cells 2020;12:100-109

143. Kaur S, Abu-Shahba AG, Paananen RO, Hongisto H, Hiidenmaa H, Skottman H, Seppänen-Kaijansinkko R, Mannerström B. Small non-coding RNA landscape of extracellular vesicles from human stem cells. Sci Rep 2018;8: 15503

144. Hanna J, Hossain GS, Kocerha J. The potential for microRNA therapeutics and clinical research. Front Genet 2019;10:478

145. Cosenza S, Ruiz M, Toupet K, Jorgensen C, Noël D. Mesenchymal stem cells derived exosomes and microparticles protect cartilage and bone from degradation in osteoarthritis. Sci Rep 2017;7:16214

146. Xu JF, Yang GH, Pan XH, Zhang SJ, Zhao C, Qiu BS, Gu HF, Hong JF, Cao L, Chen Y, Xia B, Bi Q, Wang YP. Altered microRNA expression profile in exosomes during osteogenic differentiation of human bone marrow-derived mesenchymal stem cells. PLoS One 2014;9:e114627

147. Mao G, Zhang Z, Hu S, Zhang Z, Chang Z, Huang Z, Liao W, Kang Y. Exosomes derived from miR-92a-3p-overexpressing human mesenchymal stem cells enhance chondrogenesis and suppress cartilage degradation via targeting WNT5A. Stem Cell Res Ther 2018;9:247

148. Wang $\mathrm{R}, \mathrm{Xu} \mathrm{B}, \mathrm{Xu} \mathrm{H}$. TGF- $\beta 1$ promoted chondrocyte proliferation by regulating Spl through MSC-exosomes derived miR-135b. Cell Cycle 2018;17:2756-2765

149. Sun H, Hu S, Zhang Z, Lun J, Liao W, Zhang Z. Expression of exosomal microRNAs during chondrogenic differentiation of human bone mesenchymal stem cells. J Cell Biochem 2019;120:171-181

150. Zhang X, Chang A, Li Y, Gao Y, Wang H, Ma Z, Li X, Wang B. miR-140-5p regulates adipocyte differentiation by targeting transforming growth factor- $\beta$ signaling. Sci Rep 2015;5:18118

151. Wei J, Li H, Wang S, Li T, Fan J, Liang X, Li J, Han Q, Zhu L, Fan L, Zhao RC. let-7 enhances osteogenesis and bone formation while repressing adipogenesis of human stromal/mesenchymal stem cells by regulating HMGA2. Stem Cells Dev 2014;23:1452-1463

152. Zhang WB, Zhong WJ, Wang L. A signal-amplification circuit between miR-218 and Wnt/ $\beta$-catenin signal promotes human adipose tissue-derived stem cells osteogenic differentiation. Bone 2014;58:59-66

153. Wu J, Kuang L, Chen C, Yang J, Zeng WN, Li T, Chen H, Huang S, Fu Z, Li J, Liu R, Ni Z, Chen L, Yang L. miR-100-5p-abundant exosomes derived from infrapatellar fat pad MSCs protect articular cartilage and ameliorate gait abnormalities via inhibition of mTOR in osteoarthritis. Biomaterials 2019;206:87-100
154. Bonafede R, Scambi I, Peroni D, Potrich V, Boschi F, Benati D, Bonetti B, Mariotti R. Exosome derived from murine adipose-derived stromal cells: neuroprotective effect on in vitro model of amyotrophic lateral sclerosis. Exp Cell Res 2016;340:150-158

155. Li W, Liu Y, Zhang P, Tang Y, Zhou M, Jiang W, Zhang $\mathrm{X}$, Wu G, Zhou Y. Tissue-engineered bone immobilized with human adipose stem cells-derived exosomes promotes bone regeneration. ACS Appl Mater Interfaces 2018;10: 5240-5254

156. Tao SC, Yuan T, Zhang YL, Yin WJ, Guo SC, Zhang CQ. Exosomes derived from miR-140-5p-overexpressing human synovial mesenchymal stem cells enhance cartilage tissue regeneration and prevent osteoarthritis of the knee in a rat model. Theranostics 2017;7:180-195

157. Wen S, Dooner M, Cheng Y, Papa E, Del Tatto M, Pereira M, Deng Y, Goldberg L, Aliotta J, Chatterjee D, Stewart C, Carpanetto A, Collino F, Bruno S, Camussi G, Quesenberry P. Mesenchymal stromal cell-derived extracellular vesicles rescue radiation damage to murine marrow hematopoietic cells. Leukemia 2016;30:2221-2231

158. Ribeiro A, Laranjeira P, Mendes S, Velada I, Leite C, Andrade P, Santos F, Henriques A, Grãos M, Cardoso CM, Martinho A, Pais M, da Silva CL, Cabral J, Trindade H, Paiva A. Mesenchymal stem cells from umbilical cord matrix, adipose tissue and bone marrow exhibit different capability to suppress peripheral blood $\mathrm{B}$, natural killer and $\mathrm{T}$ cells. Stem Cell Res Ther 2013;4:125

159. Montesinos JJ, Flores-Figueroa E, Castillo-Medina S, Flores-Guzmán P, Hernández-Estévez E, Fajardo-Orduña G, Orozco S, Mayani H. Human mesenchymal stromal cells from adult and neonatal sources: comparative analysis of their morphology, immunophenotype, differentiation patterns and neural protein expression. Cytotherapy 2009;11: 163-176

160. Prasanna SJ, Gopalakrishnan D, Shankar SR, Vasandan AB. Pro-inflammatory cytokines, IFNgamma and TNFalpha, influence immune properties of human bone marrow and Wharton jelly mesenchymal stem cells differentially. PLoS One 2010;5:e9016

161. Wang X, Kimbrel EA, Ijichi K, Paul D, Lazorchak AS, Chu J, Kouris NA, Yavanian GJ, Lu SJ, Pachter JS, Crocker SJ, Lanza R, Xu RH. Human ESC-derived MSCs outperform bone marrow MSCs in the treatment of an EAE model of multiple sclerosis. Stem Cell Reports 2014;3:115-130

162. Wegmeyer $\mathrm{H}$, Bröske $\mathrm{AM}$, Leddin $M$, Kuentzer $\mathrm{K}$, Nisslbeck AK, Hupfeld J, Wiechmann K, Kuhlen J, von Schwerin C, Stein C, Knothe S, Funk J, Huss R, Neubauer M. Mesenchymal stromal cell characteristics vary depending on their origin. Stem Cells Dev 2013;22:2606-2618

163. Zhang ZY, Teoh SH, Chong MS, Schantz JT, Fisk NM, Choolani MA, Chan J. Superior osteogenic capacity for bone tissue engineering of fetal compared with perinatal and adult mesenchymal stem cells. Stem Cells 2009;27: 126-137

164. Chang MG, Tung L, Sekar RB, Chang CY, Cysyk J, Dong 
P, Marbán E, Abraham MR. Proarrhythmic potential of mesenchymal stem cell transplantation revealed in an in vitro coculture model. Circulation 2006;113:1832-1841

165. Breitbach M, Bostani T, Roell W, Xia Y, Dewald O, Nygren JM, Fries JW, Tiemann K, Bohlen H, Hescheler J, Welz A, Bloch W, Jacobsen SE, Fleischmann BK. Potential risks of bone marrow cell transplantation into infarcted hearts. Blood 2007;110:1362-1369

166. Yao X, Wei W, Wang X, Chenglin L, Björklund M, Ouyang H. Stem cell derived exosomes: microRNA therapy for agerelated musculoskeletal disorders. Biomaterials 2019;224: 119492 